\title{
Effect of Storage Temperature and Periods on Some Characteristics of Wheat Flour Quality
}

\author{
Muneer Saif Hasan Ahmed \\ University of Mysore, Mysore, India \\ Email: mshyemen1@yahoo.com
}

Received 30 July 2015; accepted 21 September 2015; published 24 September 2015

Copyright (C) 2015 by author and Scientific Research Publishing Inc.

This work is licensed under the Creative Commons Attribution International License (CC BY). http://creativecommons.org/licenses/by/4.0/

(c) (i) Open Access

\section{Abstract}

A laboratory experiment has been designed and implemented to study the effects of storage temperatures $\left(27.5^{\circ} \mathrm{C}\right.$ and $37.5^{\circ} \mathrm{C}$ ) and storage periods (day, 3 days, 10 days, 20 days and 30 days) in normal conditions and relative humidity on the characteristics of wheat flour quality, as well as some of the chemical characteristics of flour (moisture content and ratio of wet gluten), the physical properties (color and falling number). Increasing the storage temperature from $27.5^{\circ} \mathrm{C}$ to $37.5^{\circ} \mathrm{C}$ has led to decreasing moisture content of flour stored under storage relative humidity of $38 \%$ - 70\%. It has also resulted in extending the storage period from 1 day to 10 days to a decrease in moisture content of flour, and this decline has increased the storage period up to thirty days. The overlap between these two factors has been significantly affective. As the storage temperature of flour increased from $27.5^{\circ} \mathrm{C}$ to $37.5^{\circ} \mathrm{C}$, the percentage of wet gluten has been increased too, and the storage period was extended to ten days. This has led to a significant increase in the percentage of wet gluten flour. In addition, there was a significant response to the effective overlap between the storage temperatures and periods of storage under study in this manner. Increasing the storage temperature from $27.5^{\circ} \mathrm{C}$ to $37.5^{\circ} \mathrm{C}$ has led to significantly increased values of the color of the stored flour. Besides, increasing the storage period one day more has led to decreasing the values of the color of the stored flour. However, there has been no significant change to the subsequent periods of storage. The overlap between both factors of temperature and storage periods has a significant effect on the flour color. There has been a significant decrease of the enzyme activity (the height values of the falling No.). But there is a noticeable increase to the falling No. values of the stored flour by $37.5^{\circ} \mathrm{C}$ when increasing the storage periods from one day to ten days and thirty days. This effect, nonetheless, has not reached the significant level.

\section{Keywords}

Wheat Flour, Bread, Storage Time, Temperature Storage, Color, Falling Number, Wet Gluten, 


\section{Introduction}

Wheat is the first food crop all over the world for being the basic raw material for the production of Flour used in making bread, and bread is a staple food for more than three quarters of the globe population, so the stability of any country, food security depends on the availability of this article, cultivation, productive and to reach its optimum consumption, as wheat is the raw material for many of the food industry in all its forms, pasta, semolina, bulgur and couscous and other uses according to the habits and patterns of peoples in different countries world.

Wheat occupies the largest share among all grain crops in terms of its presence at the tables' food, constitutes in many countries approximately $70 \%$ of its food needs, whether it is direct or indirect, and therefore it costs a lot of local and foreign currencies [1]. The amount of the world production of wheat was estimated at 713.2 million tons 2013 [2] comes the result of the increasing consumption bread and nutritional value of the human person, in terms of average global per capita consumption of wheat was about $85 \mathrm{~kg} /$ year [3]. And annual increase in global wheat consumption reached to 2\% [4].

Wheat is the most important of cereal crop in Arabic consumption pattern in general [5]. In spite of the widespread interesting of storing food for long periods but it has not been studied storage wheat flour in the long term in a wide range, especially when change and modify storage conditions [6].

The study showed [7] that the flour changes become less during storage at low temperatures and proved it in two years in storage degree $0^{\circ} \mathrm{C}$ where the flour characteristics have not changed significantly.

The flour is the output of wheat crop processor modern milling (Young Flour) improves quality, quality over a period of one month to two months, and that this improvement is associated with substantially all of the moisture content and the storage temperature and other conditions storage flour [8].

Also found that the flour moisture composite ratio increased during storage for 3 months [9].

In a study researchers [10] found that during the storage period of 15 months for US wheat flour at a temperature between $0{ }^{\circ} \mathrm{C}-25^{\circ} \mathrm{C}$ and relative humidity $28 \%$ and $73 \%$ that the flour characteristics have changed during the ripening process.

The [11] has stated that the chemical changes emerged during the 4 - 5 days of milling and lasted for 3 weeks almost, and concluded that the process of ripening important to get an accurate perfect bread despite the fact that this period was affected by several factors, including the time of ripening and the characteristics of flour and conditions storage surroundings.

And it explained the study carried out by the [12] that cannot keep the delicate quality resulting from the wheat grain moisture $15 \%$ for more than six months and a degree $25^{\circ} \mathrm{C}$, or more than 15 days for an accurate result of the wheat humidity of $18 \%$ under $25^{\circ} \mathrm{C}$-and its quality to deteriorate more rapidly in $34^{\circ} \mathrm{C}$ degree at this level of humidity. And on the contrary, it was stated [13] that showed when the flour storage at $25^{\circ} \mathrm{C}$ deterioration rate more quickly and inferred through decomposition lypolysis compared with flour stored on $12^{\circ} \mathrm{C}$.

And in general has explained the study [14] that the positive effect of temperature on the flour quality extent of within $10^{\circ} \mathrm{C}$ to $30^{\circ} \mathrm{C}$, while the flour storage at high temperatures such as tropical countries and Summery Climate, increases the rate of deterioration flour faster.

Because of the need to assess the extent of changes in the quality of wheat flour and its properties, under possible storage conditions, purpose of this study was to:

Study the effect of temperature and storage period on the characteristics of flour quality.

Study the interaction relationship between each of the temperature and duration of storage and their impact on the main chemicals and physics characters commercialized on wheat flour.

\section{Materials and Methods}

To achieve the objectives of the research are designed laboratory experiment was carried out in the laboratories of Yemen Company for Grain Silos and Flour Mills Yemen, All the data were statistically analyzed by analysis of variance (ANOVA) as applicable to a randomized complete block design (RCBD), and were compared as for 
Duncan's least significant difference test at $\mathrm{p}<0.05$. All statistical analyses were carried out using the SAS program, Version 9.1 (SAS System 2004).

\subsection{Study Materials}

\subsubsection{Raw Wheat}

The Class used in the flour to these samples to study is Soft wheat French origin.

Where the production of flour milling after the cleaning stages and Wheat Hydration with water for 24 hours in the company's mills, a modern cylindrical mills Buhler Swiss company.

1) Flour

The study was conducted on the output flour of grinding and extraction by almost $76 \%$, where according to the standard specifications in the flour production by Moisture does not exceed $14 \%$, by protein not less than $10 \%[15]$.

2) Salt

Product salt was used in Pakistan carries the name brand (King) containing 0.07\% iodide Potassium, sodium bicarbonate and Brosna yellow soda.

\subsubsection{Devices Used}

1) Measuring the temperature and the relative air humidity device (Digital Thermometer MT-2-) equipped from the KI \& BNT company, Chinese.

2) Device estimate moisture (Air oven) equipped from (Heraeus Thermo Electron of the company corporation) Germany.

3) Device estimate the degree of color (Color grader series IV) from British Satake company.

4) Device estimate falling number (Falling no 1500) equipped from Perten company, Germany.

5) Sensitive electronic balance (Analytical Balance $220 \mathrm{~g}$ ) degree of accuracy $0.1 \mathrm{mg}$-equipped from Sartarius company, Germany.

\section{Study Transactions}

First factor: degrees Storage temperature e(A).

1) Adjusting the stored heat to 27.5 Celsius (A1) \pm 0.5 .

2) Adjusting the stored heat to 37.5 Celsius (A2) \pm 0.5 .

Second factor: intervals Storage

1) Flour stored for a day (B1).

2) Flour stored for 3 days (B2).

3) Flour stored for 10 days (B3).

4) Flour stored for 20 day (B4).

5) Flour stored for 30 days (B5).

Flour were collected samples in PP bags of $25 \mathrm{~kg}$ capacity at final production line, and stored in a suitable location to provide a degree of storage required temperature by conditioning device talk (split) contains a sensor to measure the temperature and is set to the required degree, has also been measure and control temperature accuracy by a special device that has Tssen together the first to measure the temperature, and the second for measuring relative air humidity.

And study samples have been stored in a small store size of $4 \times 4 \times 8$ meters has been allocated for this purpose with varying degrees of heat $\mathrm{A}\left(27.5^{\circ} \mathrm{C}\right.$ and $\left.37.5^{\circ} \mathrm{C} \pm 0.5^{\circ} \mathrm{C}\right)$ and for different periods of storage $\mathrm{B}$ (day, 3 days, 10 days, 20 days, 30 days) and were followed up and record the natural relative humidity percentages, as well as temperatures in the atmosphere storage by six readings per day for the first treatment (temperature $27.5^{\circ} \mathrm{C}$ ) and for the treatment of second (temperature $37.5^{\circ} \mathrm{C}$ ) distributed at the beginning of the day and the middle and end during the period study (two months), May and June. During the study has a degree Storage temperature $27.5^{\circ} \mathrm{C} \mathrm{A} 1-$, and in June and July. The study was conducted on the storage temperature $37.5^{\circ} \mathrm{C} \mathrm{A} 2$ was sufficient here to explain the three readings recorded in the days of access to the storage periods It required a day and 3 days, 10 days and 20 days and 30 days as it is written in Table 1 and Table 2.

\section{Chemical Properties of the Flour}

1) Moisture content (\%): moisture content was estimated according to the method ICC [16]. 
Table 1. Temperature readings at $27.5^{\circ} \mathrm{C} \pm 0.5^{\circ} \mathrm{C}$, and storage relative air humidity (three readings for each storage period).

\begin{tabular}{lccc}
\hline Time & Storage period & Temperature $\left({ }^{\circ} \mathrm{C}\right)$ & Relative humidity \% \\
$6.30 \mathrm{am}$ & day & 27.5 & $44 \%$ \\
$2.30 \mathrm{pm}$ & day & 27.6 & $48 \%$ \\
$8.30 \mathrm{pm}$ & day & 27.0 & $54 \%$ \\
$6.30 \mathrm{~mm}$ & 3 days & 27.2 & $44 \%$ \\
$2.30 \mathrm{pm}$ & 3 days & 27.0 & $42 \%$ \\
$8.30 \mathrm{pm}$ & 3 days & 27.0 & $42 \%$ \\
$6.30 \mathrm{~mm}$ & 10 days & 27.0 & $40 \%$ \\
$2.40 \mathrm{pm}$ & 10 days & 27.1 & $43 \%$ \\
$8.00 \mathrm{pm}$ & 10 days & 27.0 & $40 \%$ \\
$6.30 \mathrm{am}$ & 20 days & 27.0 & $38 \%$ \\
$2.00 \mathrm{pm}$ & 20 days & 27.0 & $47 \%$ \\
$8.00 \mathrm{pm}$ & 20 days & 27.3 & $43 \%$ \\
$6.30 \mathrm{am}$ & 30 days & 27.6 & $51 \%$ \\
$2.30 \mathrm{pm}$ & 30 days & 27.1 & $51 \%$ \\
$8.30 \mathrm{pm}$ & 30 days & 27.7 & $45 \%$ \\
\hline
\end{tabular}

The number of readings taken during the month 202 Average temperatures taken $27.41 \mathrm{~m}$. Table showing only readings of temperature and relative humidity weather at the end of each period Storage,. The natural relative humidity ranged between $38 \%$ - $54 \%$.

Table 2. Temperature readings at $27.5^{\circ} \mathrm{C} \pm 0.5^{\circ} \mathrm{C}$, and storage relative air humidity (three readings for each storage period).

\begin{tabular}{lccc}
\hline Time & Storage period & Temperature $\left({ }^{\circ} \mathrm{C}\right)$ & Relative humidity $\%$ \\
\hline $6.30 \mathrm{~mm}$ & day & 37.9 & $62 \%$ \\
$2.30 \mathrm{pm}$ & day & 37.0 & $49 \%$ \\
$8.30 \mathrm{pm}$ & day & 37.0 & $47 \%$ \\
$6.30 \mathrm{am}$ & 3 days & 37.5 & $51 \%$ \\
$2.30 \mathrm{pm}$ & 3 days & 37.0 & $48 \%$ \\
$8.30 \mathrm{pm}$ & 3 days & 37.8 & $51 \%$ \\
$6.30 \mathrm{am}$ & 10 days & 36.8 & $66 \%$ \\
$2.40 \mathrm{pm}$ & 10 days & 37.0 & $70 \%$ \\
$8.00 \mathrm{pm}$ & 10 days & 37.6 & $51 \%$ \\
$6.30 \mathrm{am}$ & 20 days & 37.3 & $56 \%$ \\
$2.00 \mathrm{pm}$ & 20 days & 37.2 & $60 \%$ \\
$8.00 \mathrm{pm}$ & 20 days & 37.4 & $56 \%$ \\
$6.30 \mathrm{am}$ & 30 days & 37.0 & $48 \%$ \\
$2.30 \mathrm{pm}$ & 30 days & 38.00 & $40 \%$ \\
$8.30 \mathrm{pm}$ & 30 days & 37.8 & $54 \%$ \\
Number of reading recorded & 176 & 176 \\
\hline
\end{tabular}

The number of readings taken during the month 176 . Average temperatures taken $37.42^{\circ} \mathrm{C}$. Table showing only readings of temperature and relative humidity weather at the end of each period Storage, The natural relative humidity ranged between $48 \%-70 \%$ studied traits. 
2) Ratio of wet gluten (\%): was estimated according to the method ICC [16].

\section{Physical Properties of the Flour}

1) Color: the flour color test according to the method of work set out in Annex guide device by the manufacturer (British Satake Corporation).

2) Falling number (seconds): the falling number test for estimating the enzymatic activity according to the method ICC (16).

\section{Statistical Analysis}

The analysis of the data has been taken in four replications using fully random design and global averages comparison between test by test teams less moral amended Revised LSD [17].

\section{Results and Discussion}

\subsection{The Impact of Degrees Storage Temperature and Periods on the Chemical Characteristics}

\subsubsection{The Moisture Content in the Flour}

Evidenced by the results of the study in Table 3 that the storage temperature significant effect on the proportion of flour moisture, moisture has decreased and significant differences are very high, where the average moisture flour dropped from $12.6 \%$ at Storage under degree $27.5^{\circ} \mathrm{m}$ temperature to $11.7 \%$ at stored under $37.5^{\circ} \mathrm{m}$ degree heat, and the margin calculated as a percentage amount of approximately $12 \%$. This may be due to high storage temperature that led to the evaporation of moisture from the part.

It was reported [18] that the flour storage relative humidity in theatmosphere leads to high absorption amount of moisture, especially if the small pack ages and also vice versa if there lative humidity is low, the flour loses part of moisture.

Findings also show in the Table 3 that periods of storage have affected significant effect on this trait, the proportion of flour moisture was significantly decreased by increasing storage period from one day to 10 days as a percentage calculated the amount of $10.5 \%$, while the average dropped moisture accurate, up storage period to 30 days, a decline of $15.6 \%$ and did not notice any significant differences in the moisture content of the flour when increasing the storage period for a period of 20 - 30 days. These results differ with [19], which found that the storage of whole wheat Compatible with NaFe EDTA accurate, elemental iron and ZnO stock funds in polypropylene bags for 60 days under the conditions of normal storage led to a lack of non-moral in humidity. Also found [20] that the flour moisture composite ratio increased during the storage period of 3 months.

The results of the study conducted by [21] that the grains flour full of millet storage at temperatures from $20^{\circ} \mathrm{C}$ to $27^{\circ} \mathrm{C}$ with relative humidity between $60 \%$ and $70 \%$ and two storage of 10 and 20 days in polythene bags led to high moisture content of the flour. While this study indicate to the existence of a significant effect of overlap between these two factors By increasing both the temperature and the period of storage to $37.5^{\circ} \mathrm{C}$ and 30 days, respectively, decreased flour moisture compared to a safety deposit box at temperatures Storage temperature and at least epochs, where the percentage calculated amounted to a reduction in moisture content of the flour about $23 \%$. Moral decline in the moisture content of the flour stored as observed for 30 days under $27.5^{\circ} \mathrm{C}$, which amounted to $11.7 \%$ to $10.6 \%$ at high temperature to $37.5^{\circ} \mathrm{C}$, and the low rate calculated as a percentage reached 21.7\% Figure 1 \& Figure 2. This is due to the high moisture content of the flour (approximately 14\%)

Table 3. The effect of storage temperature and his term on the flour percentage of moisture (\%).

\begin{tabular}{cccccccc} 
& $\mathrm{B}_{1}$ & $\mathrm{~B}_{2}$ & $\mathrm{~B}_{3}$ & $\mathrm{~B}_{4}$ & $\mathrm{~B}_{5}$ & Means & LSD, 5\% \\
\hline A1 & 13.7 & 13.5 & 12.6 & 11.2 & 11.7 & 12.6 & 0.49 \\
$\mathrm{~A} 2$ & 13.8 & 12.2 & 11.2 & 11.0 & 10.6 & 11.1 & \multirow{2}{*}{} \\
Means & 13.75 & 12.85 & 11.92 & 11.10 & 11.13 & & \\
LSD, 5\% & & & 0.51 & & & & \\
\hline
\end{tabular}

A1: $27.5^{\circ}, \mathrm{A} 2: 37.5^{\circ}$, B1: day, B2: 3 days, B3: 10 days, B4: 20 days, B5: 30 days. 


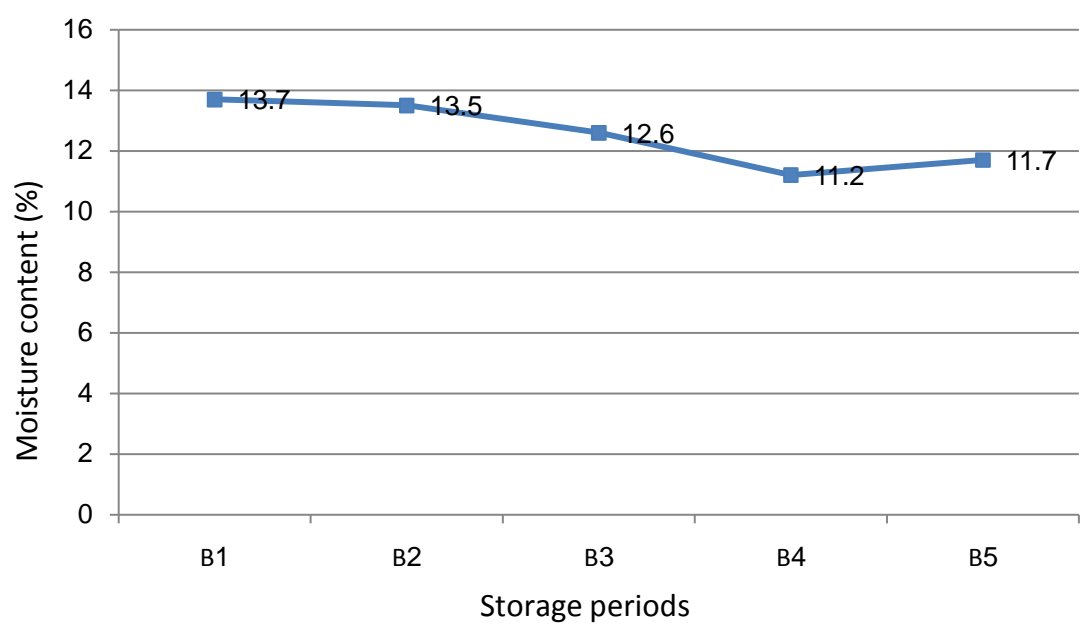

Figure 1. The effect of overlap between the temperature of 27.5 and periods of storage on the moisture content in the flour.

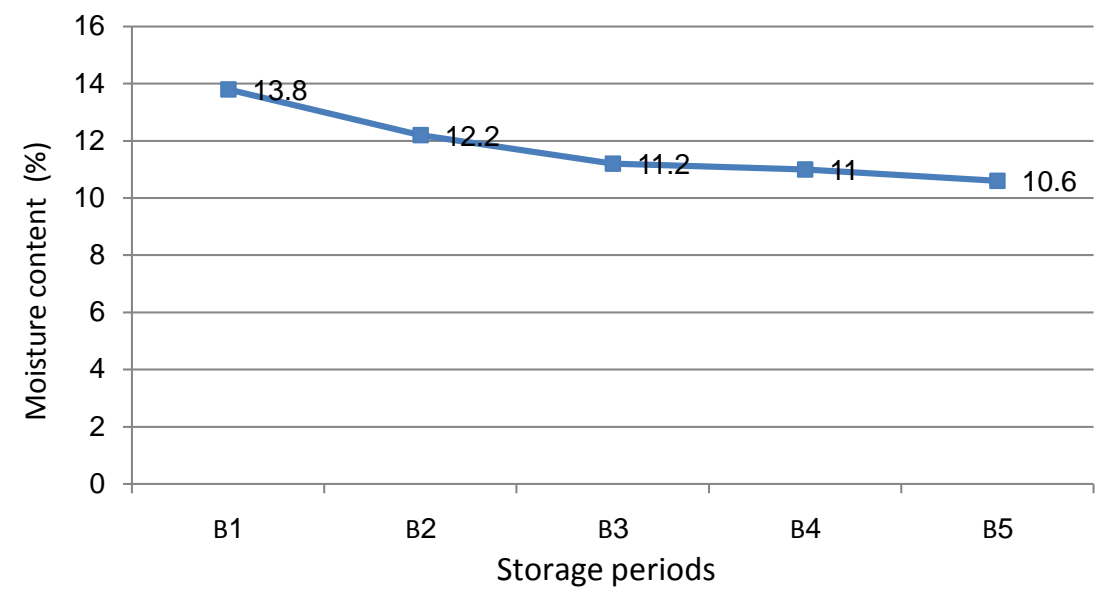

Figure 2. the effect of overlap between the temperature of 37.5 and periods of storage on the moisture content in the flour.

at the beginning of storage-with low relative humidity somewhat, leading to a transfer moisture to balance moisture and humidity firming then.

\subsubsection{The Ratio of Wet Gluten in the Flour}

Table shows data (4) the presence of significant differences between the proportions of wet gluten in the flour impact of storage temperature where the proportion of wet gluten in the flour store, up the temperature rose, reaching $25.95 \%$ at $37.5^{\circ} \mathrm{C}$ class and an increase of $1.86 \%$ compared to storage at a temperature $27.5^{\circ} \mathrm{C}$. These findings are consistent with those indicated by [22] which found that heating the soft wheat flour on $80^{\circ} \mathrm{C}$ degree heat for 15 minutes increased the proportion of wet gluten, where he was gluten easier reclaimed, while these results are not consistent with those indicated by the [23], which was found in his study that the gluten extracted from different wheats which has been treated with varying degrees are $25^{\circ} \mathrm{C}, 40^{\circ} \mathrm{C}, 50^{\circ} \mathrm{C}, 60^{\circ} \mathrm{C}, 70^{\circ} \mathrm{C}, 90^{\circ} \mathrm{C}$ heat for 20 minutes, it was observed decrease in quantity extracted from them. As pointed out [24] that the bad effect of high temperatures on the gluten due to increased break ties hydrophobic, which leads to bad influence on the strength of gluten. Flour for different time periods store led to a significant difference between wet gluten flour ratios.

Where Table data showed (4) significant differences for the proportion of wet gluten to increase the storage period with the exception of storage for a day, 3 days and which was not between them any significant differences, and possibly due to the flour newness Young Flour and generally ratio gluten wet amounted to 23.37\% 
and $26.39 \%$ when stored for a day for a period of 30 days in a row, while the proportion of the calculated increase in gluten wet almost $11 \%$ compared with the storage for a day, and these results are not consistent with [25], which it found that the length of the careful storage of wheat have limited impact on the amount of wet gluten, also found [20] a decrease in total protein flour ratio of the length of the period of storage. These results differ from those found here [26] that the flour characteristics of the store for a long period of change has been attributed to the reason for this is the flour effect acids unsaturated fatty during storage and which can reduce the swelling of gluten.

Results shown in Table 4 that there was a significant response to the impact of the overlap between degrees Storage temperature and periods of storage under study, noting that there is a significant increase of the proportion of gluten wet when the flour storage varying $37.5^{\circ} \mathrm{C}$, and when increasing the storage period from one day to three days believe 3 days to 10 days or 10 days to 20 days or 20 days to 30 days, and notes that the highest percentage of gluten wet flour was obtained when the storage for a period of 30 days and under degree $37.5^{\circ} \mathrm{C}$ temperature stood at $28.71 \%$, while the differences Storage between periods under study did not reach the level of significance when $27.5^{\circ} \mathrm{C}$ Storage on the degree of heat Figure 3 \& Figure 4. These results vary with the study [27] which indicated that the flour output of wheat stored in solid Hrarh $34.8^{\circ} \mathrm{C}$ degrees and relative humidity of 66.7\% for the periods 45-90-135 day event in which a lack of both protein and gluten during Storage In all periods, while consistent with the results [28] which showed that an accurate inventory Millet in cans for 8 days under room temperature $25^{\circ} \mathrm{C} \pm 5^{\circ} \mathrm{C}$ the crude protein content has increased clearly during the period of storage.

\subsection{The Impact of Degrees Storage Temperature and Epochs on Some Physical Properties of the Flour}

\subsubsection{The Flour Color}

Results in Table 5 the existence of significant differences between the flour color values of the impact of degrees Storage temperature under study, which notes that there is a high for the average color values (2.85) measured in the flour at the end of the storage process temperature $37.5^{\circ} \mathrm{C}$ compared to the flour color values stored under $27.5^{\circ} \mathrm{C}(2.53)$.

Results of the study appear in the same table that the storage periods was significantly affecting the degree of color in the flour where the storage period increased from one day to a significant decrease of color. However, there has been no significant change Storage subsequent periods. This means that the storage period (after the rest of the flour milling process directly) necessary for the occurrence of the necessary changes. And that the changes in the color of storage for 20 days is the best Figure 5 \& Figure 6.

Table 4. The effect of storage temperature and his term on wet gluten (\%).

\begin{tabular}{cccccccc}
\hline & B1 & B2 & B3 & B4 & B5 & Means & LSD, 5\% \\
\hline A1 & 23.5 & 23.2 & 24.8 & 24.9 & 24.1 & 24.09 & 0.89 \\
A2 & 23.2 & 24.8 & 26.0 & 27.6 & 28.7 & 25.95 & 1.8 \\
Means & 23.37 & 23.98 & 25.38 & 26.23 & 26.39 & & \\
LSD, 5\% & & & 1.11 & & & & \\
\hline
\end{tabular}

A1: $27.5^{\circ}, \mathrm{A} 2: 37.5^{\circ}, \mathrm{B} 1:$ day, B2: 3 days, B3: 10 days, B4: 20 days, B5: 30 days.

Table 5. The effect of storage temperature and his term on the flour color character.

\begin{tabular}{cccccccc} 
& B1 & B2 & B3 & B4 & B5 & Means & LSD, 5\% \\
\hline A1 & 2.733 & 2.566 & 2.466 & 2.433 & 2.466 & 2.533 & 0.088 \\
A2 & 3.233 & 2.800 & 2.800 & 2.700 & 2.733 & 2.853 & \\
Means & 2.98 & 2.68 & 2.63 & 2.57 & 2.59 & & 0.101 \\
LSD, 5\% & & & 0.12 & & & & \\
\hline
\end{tabular}

A1: $27.5^{\circ}, \mathrm{A} 2: 37.5^{\circ}, \mathrm{B} 1:$ day, B2: 3 days, B3: 10 days, B4: 20 days, B5: 30 days. 


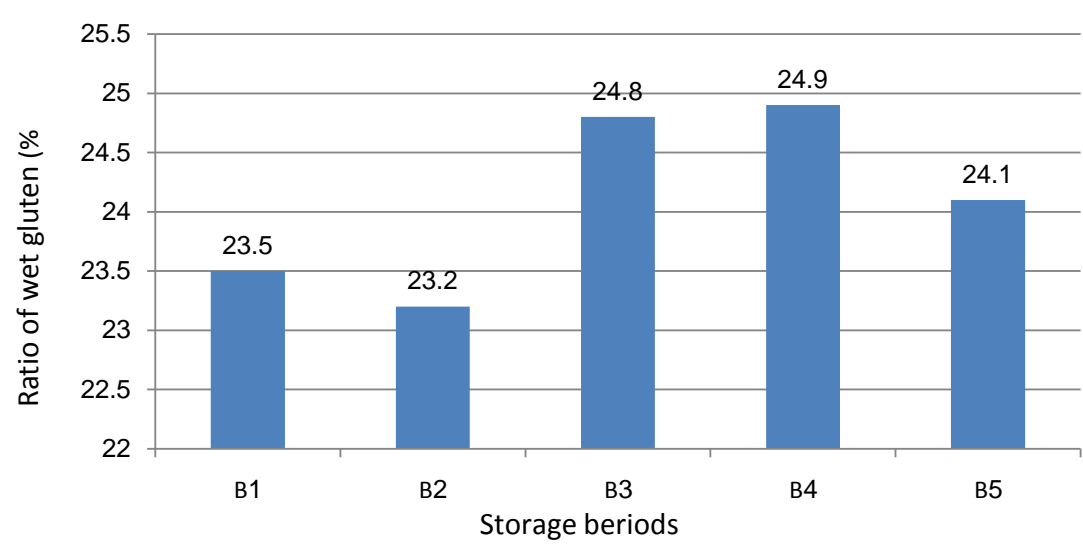

Figure 3. The effect of overlap between the temperature of $27.5^{\circ} \mathrm{C}$ and periods of storage on the gluten content in the flour.

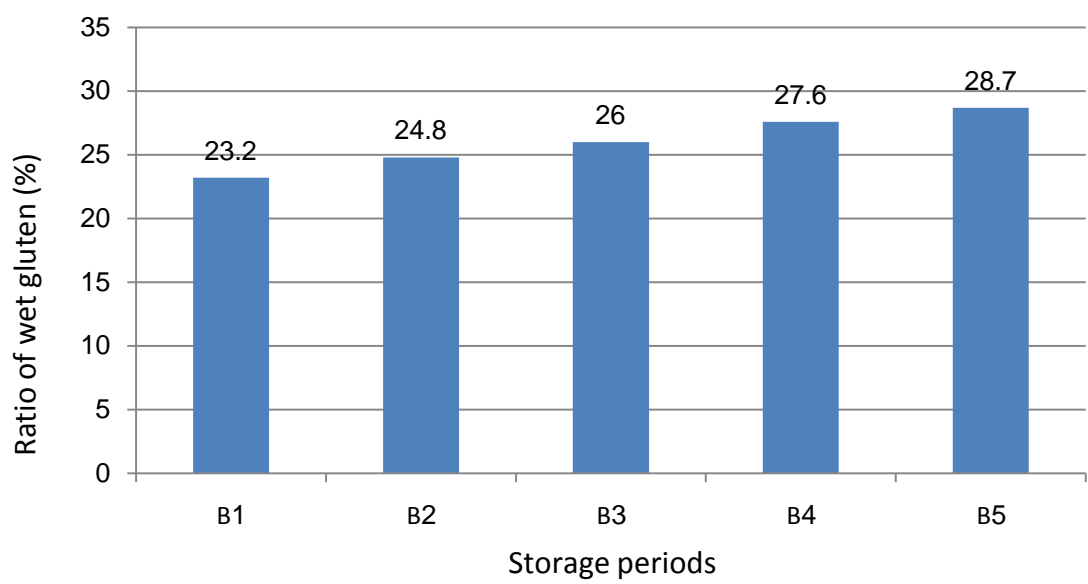

Figure 4. The effect of overlap between the temperature of $37.5^{\circ} \mathrm{C}$ and periods of storage on the gluten content in the flour.

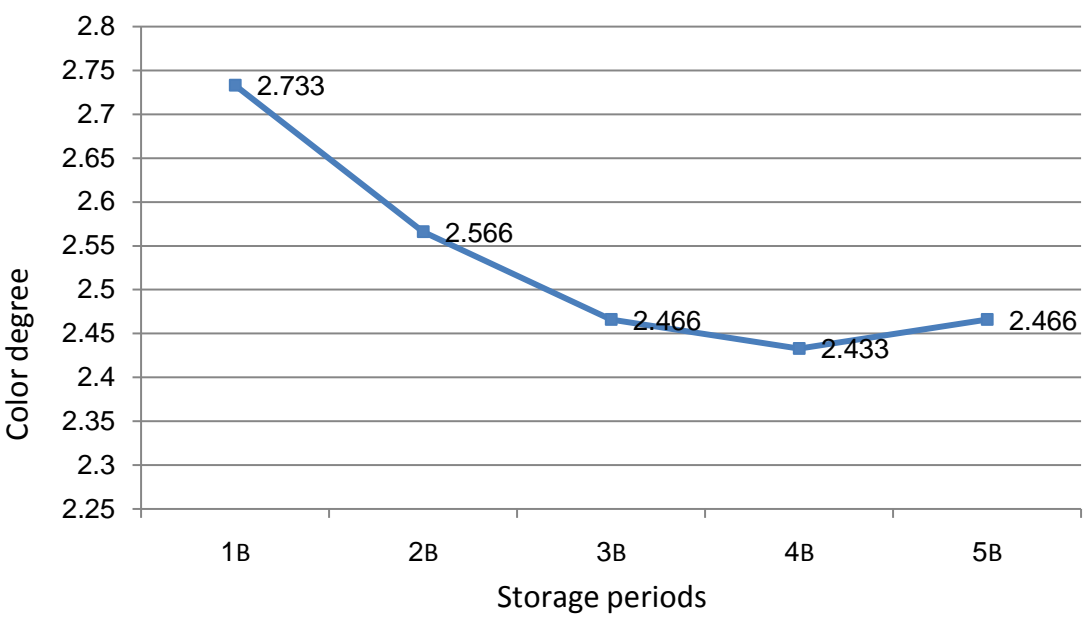

Figure 5. The effect of overlap between the temperature of $27.5^{\circ} \mathrm{C}$ and periods of storage status in the flour color.

The same data as the table shows that the degree of overlap between the storage temperature and storage period significant effect, since the color values decreased in both degrees Storage temperature $27.5^{\circ} \mathrm{C}$ and $37.5^{\circ} \mathrm{C}$ 


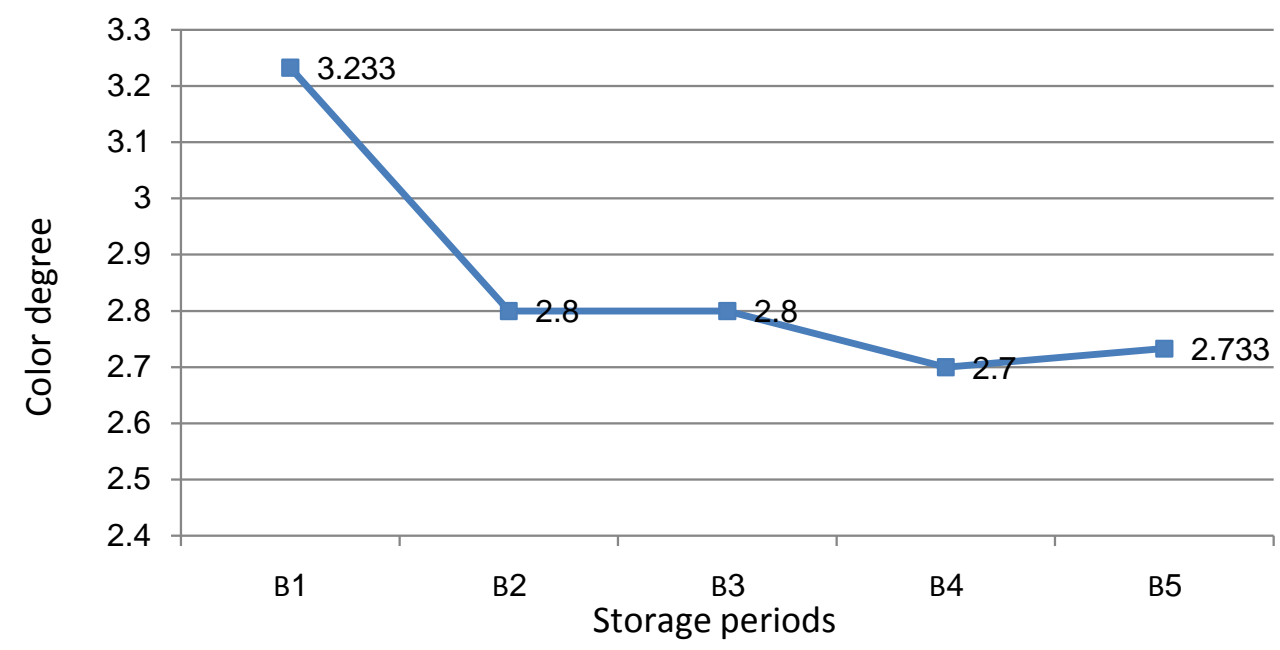

Figure 6. The effect of overlap between the temperature of $37.5^{\circ} \mathrm{C}$ and periods of storage status in the flour color.

As noted, has given storage period of 20 days under each of the two-degree maximum degree a decrease in color, in a temperature storage $27.5^{\circ} \mathrm{m}$ color decreased from 2.73 at the storage for a day until 2:43 at 20 days storage in Storage $37.5^{\circ} \mathrm{C}$ degree color temperature decreased from 3.23 at the storage for a day until 2.70 when the storage for 20 days also.

Impairment flour color high temperature and increase the storage period is normal values may be due to the continued storage process under these circumstances encourages oxidation self-dyes flour existing naturally in the flour and the presence of atmospheric oxygen and enzymes to help it (enzyme Alliboksgniz), and these results are consistent with [18] to be flour, which is ripening during storage, it is expected that the change is happening in color, Where he was to study the precise storage output of many varieties for 2 to 3 months at ambient temperature, and for several months on the degree of $39^{\circ} \mathrm{m}$ heat, and a shortage of pigments carotenoids has occurred during the term of the flour storage, and found that over 5 years storage flour and the concentration of lutein esters reduced by $30 \%$ to $50 \%$, and the shortage that occurs in the free lutein (ineffective) could be observed after a year and a half of the storage.

\subsubsection{The Falling Number of Flour}

It is clear from the data Table 6 that there is an increase in the value of the falling number at higher storage temperature, has given the degree of Storage top temperature average higher falling number compared to the degree least Storage temperature, which indicates that there is a decline in activity enzymatic high storage temperature was (1) has pointed out that the falling number inversely proportional to the activity of enzymes alpha-amylase, is the high activity of this enzyme in wheat flour undesirable and has a negative effect on the properties of bread dough so every precise types of bread should be the fall of the number ranges between 250 300 seconds.

On the other hand, he found [29] that the addition of the alpha-amylase enzyme with transglutaminase enzyme to white flour and flour full recovery led to the production of bread softer and softer.

The results of the statistical analysis in the Table 6 to have a significant effect for periods of storage under study on the status of the falling number in the flour, as there are up significantly for the average falling number of accurate, up periods of storage to 10 days and 30 days, compared to the storage and one day.

Values falling number of flour varied impact of overlap between degrees Storage temperature and epochs, as the results indicate the Table 6 the lack of a significant effect between global values of the Activity enzymatic flour stored at a temperature $27.5^{\circ} \mathrm{C}$ progress periods of storage, while the observed higher values of falling number of flour $37.5^{\circ} \mathrm{m}$ stored on, and by increasing storage periods from one day to 10 days and 30 days, but did not reach the level of significance Figure 7 \& Figure 8. These findings are consistent with what indicated by [26] happen in high falling number of flour stored for 3 months high temperature storage and increase his term. 
Table 6. The effect of storage temperature and his term on the falling number (seconds).

\begin{tabular}{cccccccc}
\hline & B1 & B2 & B3 & B4 & B5 & Means & LSD, 5\% \\
\hline A1 & 335.7 & 333.7 & 333.3 & 334.3 & 336.7 & 333.9 & 10.56 \\
A2 & 359.7 & 363.3 & 394.7 & 387.3 & 395.3 & 380.7 & \\
Means & 344.50 & 353.00 & 369.00 & 360.83 & 366.00 & & 40.33 \\
LSD, 5\% & & & 16.68 & & & &
\end{tabular}

A1: 27.5 $, \mathrm{A2}: 37.5^{\circ}, \mathrm{B} 1:$ day, B2: 3 days, B3: 10 days, B4: 20 days, B5: 30 days.

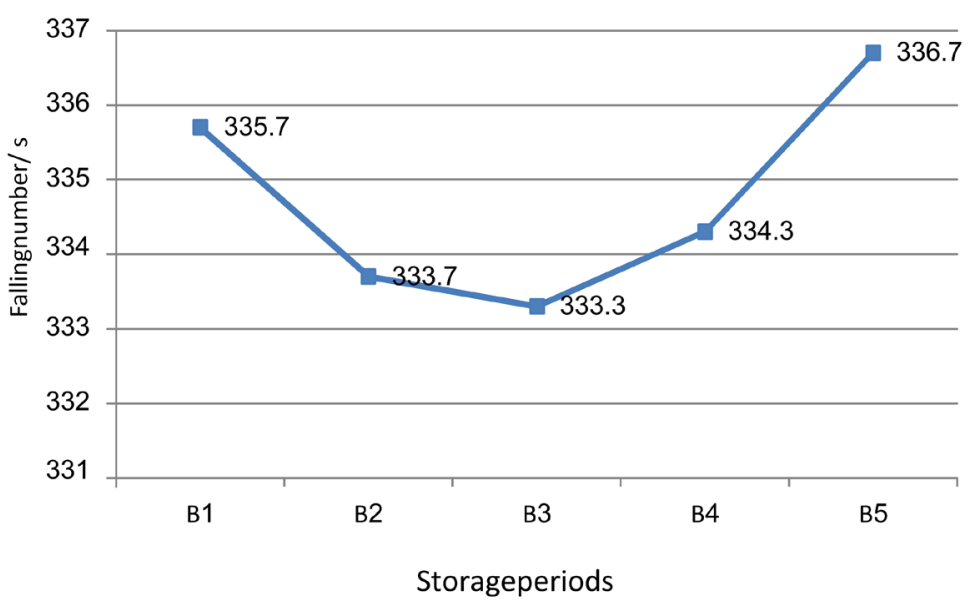

Figure 7. The effect of overlap between the temperature of $27.5^{\circ} \mathrm{C}$ and periods of storage on the value of the falling number of flour.

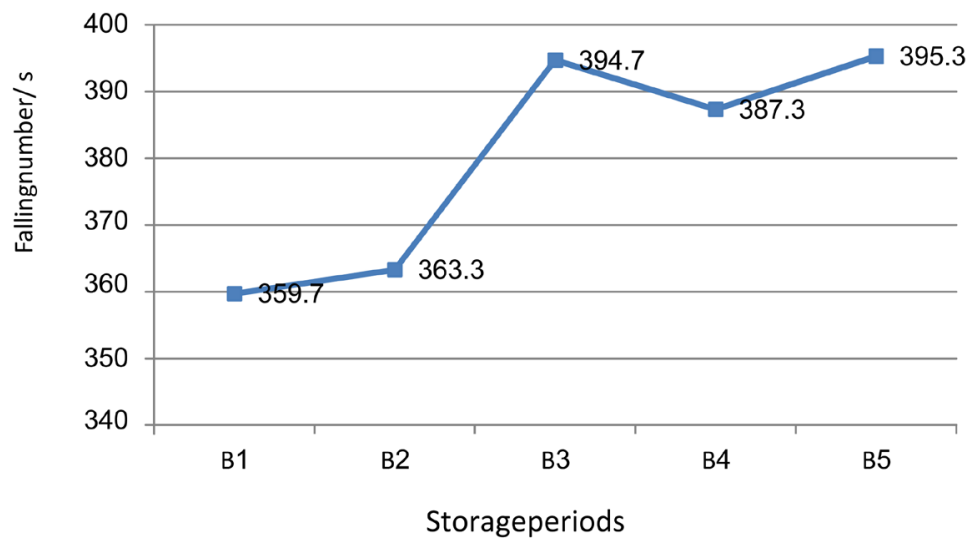

Figure 8. The effect of overlap between the temperature of $37.5^{\circ} \mathrm{C}$ and periods of storage on the value of the falling number of flour.

\section{Conclusions}

- The flour storage for a period of three days until twenty days on the degree of $37.5^{\circ} \mathrm{C} \pm$ temperature of 0.5 degrees Celsius and the average year relative humidity 59\%, but storage for a period of 10 days and even over low heat 20 days $\left(27.5^{\circ} \mathrm{C} \pm 0.5^{\circ} \mathrm{C}\right)$ and average relative humidity of $46 \%$, led to a significant reduction in the percentage of moisture flour.

- Flour stored for 30 days and in a range of temperatures from $27.5^{\circ} \mathrm{C}-37.5^{\circ} \mathrm{C} \pm 0.5^{\circ} \mathrm{C}$ to a significant increase (show the underlying qualities of the flour) in the ratio of wet gluten.

- Storage periods not more than 3 days no significant effect on the flour color, with storage under high temperatures $\left(37.5^{\circ} \mathrm{C} \pm 0.5^{\circ} \mathrm{C}\right)$ leads to a rise in the flour color values. 
- According to the type of flour under study, the degree of storage under $27.5^{\circ} \mathrm{C} \pm 0.5^{\circ} \mathrm{C}$ and relative humidity of $38 \%-54 \%$, it has led to obtaining a suitable number fall. While the temperature was raised to $37.5^{\circ} \mathrm{C} \pm$ $0.5^{\circ} \mathrm{C}$ and relative humidity of $48 \%-70 \%$ showed higher values for the falling number.

\section{References}

[1] Kunzel, Hassan, M.O. and Ali, M. (2008) A Comparative Study of Some Wheat Varieties. In the Most Important Physical Properties and Chemical and Riologih. Yemeni Journal of Agricultural Research, 27, 111-125.

[2] FAO Food and Agriculture Organization (2013) International Wheat Production Statistics.

[3] Muharram, I.A. (2009) Scientific Symposium Sixth Day Loaf Importance of the Arab-Grain Cultivation in the Food Security. Hodeidah, 18, 7-12.

[4] IGC-WGS (1996) International Grain Council, World Grain Statistics. Journal of Agriculture and Biology, 5, $458-459$.

[5] Ali Dib, T. and Susi, F. (2004) The Study of the Evolution of Wheat Consumption in the Syrian Arab Republic. Damascus University Journal of Agricultural Sciences, 20, 191-213.

[6] Dickey, N.M., Rose, D.J., Ogden, L.V. and Pike, O.A. (2004) Effects of Long Term Storage on Wheat Flour Packaged in Allow Oxygen Atmosphere. Nutrition, Dietetics and Food Science.

[7] Yoneyama, T., Suzuka, I. and Murohashi, M. (1979) Natural Maturing of Wheat Flour. I. Changes in Some Chemical Components and in Farinograph and Extensigraph Properties. Cereal Chemistry, 47, 19-26.

[8] Cenkowski, S., Dexter, J.E. and Scanlon, M.G. (2000) Mechanical Compaction of Flour: The Effect of Storage Temperature on Dough Rheological Properties. Canadian Agriculture Engineering, 42, 33-41.

[9] Almusali, M.S. and Ba Sombol, F.A. (2009) Storage Effect in Some Recipes Quality Composite of Wheat Flour, Corn Alrafeeh. Yemeni Journal of Agricultural Research, 19, 5-10.

[10] Pyler, E.J. (1973) Baking Science and Technology. Seibel Pub Com, 358-364.

[11] Lukow, O.M. and White, N.D. (1997) Influence of Ambient Storage Condition on the Breadmaking Quality of Two HRS Wheats. Journal of Stored Products Research, 31, 279-289. http://dx.doi.org/10.1016/0022-474X(95)00027-5

[12] Bothast, R.J., Anderson, R.A., Warner, K. and Kwolek, W.F. (1981) Effect of Moisture and Temperature on Microbiological and Sensory Properties of Wheat Flour and Corn Meal during Storage. Cereal Chemistry, 58, 309-311.

[13] Bell, B.M., Chamberlain, N., Collins, T.H., Daniels, D.G.H. and Fisher, N. (1979) The Composition, Rheological Properties and Bread Making Behavior of Stored Flour. Journal of the Science of Food and Agriculture, 30, 1111-1122. http://dx.doi.org/10.1002/jsfa.2740301202

[14] Wolter, K. (1986) Flour Quality Flour Storage Flour Temperature. Allgemeine Baecker Zeitung, 41, 3-4, 6.

[15] Standard Specifications Yemeni No. 51/2005. General Authority for Standardization and Metrology and Quality Control of Yemen.

[16] ICC Standard No. 110 (Moisture), 106 (Gluteen), 107 (Falling Number), Standard Methods of the ICC (2006) International Association for Cereal Science and Technology. Vienna, Austrlia.

[17] Khasheh, A. and Allah, M.K. (1980) Design and Analysis of Experiments Agricultural. Faculty of Agriculture, Iraq University, Mosul.

[18] Mahmoud, H. and Abdel-Halim, M. (1994) Monitoring the Quality of Wheat and Dairy Products Manufacturer—Part I. Alneshracharkh Holding Rackets and Almills, 253.

[19] Akhtar, S., Anjum, F.M., Rehman, S.U., Sheikh, M.A. and Farzana. K. (2008) Effect of Fortification on Physico-Chemical and Microbiological Stability of Whole Wheat Flour. Food Chemistry, 110, 113-119. http://dx.doi.org/10.1016/j.foodchem.2008.01.065

[20] Naureen, S., Masood, S., Butt, S., Rehman, S.U. and Kamran, S. (2005) Chemical Characteristics of Various Composite Flours. International Journal of Agriculture and Biology, 1560-1853.

[21] Dahiya, S. and Kapoor, A.C. (1983) Effect of Storage Conditions on the Protein Quality of Pearl Millet Flour. Nutrition Reports International, 28, 1351-1359.

[22] Gelinas, P. and McKinnon, C.M. (2004) Effect of Flour Heating on Dough Rheology. Food Research and Development Centre, Agriculture and Agri-Food, Canada.

[23] Stathopoulos, C.E., Tsiami, A.A., Schofield, J.D. and Dobraszczyk, B.J. (2007) Effect of Heat on Rheology, Surface Hydrophobicity and Molecular Weight Distribution of Glutens Extracted from Flours with Different Bread-Making Quality. Journal of Cereal Science, 47, 134-143.

[24] Amjad Boya, S. (1990) Bread and Almajnat-Mosul University/Ministry of Higher Education and Scientific Research. Iraq, 30-60. 
[25] Mis, A. (2003) Influence of the Storage of Wheat Flour on the Physical Properties of Gluten. Vol. 17, Institute of Agrophysics, Polish Academy of Sciences, Dooewiadczalna 4, 71-75.

[26] HruŠkovÁ, M. and MachovÁ, D. (2002) Changes of Wheat Flour Properties during Short Term Storage. Czech Journal of Food Sciences, 20, 125-130.

[27] Sur, R., Nagi, H.P.S., Sharma, S. and Sekhon, K.S. (1993) Storage Changes in the Quality of Sound and Sprouted Flour. Plant Foods for Human Nutrition, 44, 35-44. http://dx.doi.org/10.1007/BF01088481

[28] Boora, P. and Kapoor, A.C. (1985) Influence of Storage on the Protein Quality of Pearl Millet Flour. Journal of the Science of Food and Agriculture, 36, 59-62.

[29] Collar, C. (2007) Impact of Enzymes on the Quality Profiles of Wheat Flour Matrixes: From Dough to Stored Bread Technologists. Proceedings of 4th International Congress "Flour-Bread 07" and 6th Croatian Congress of Cereal Technologists, 24-27, 7-14. 